DOI: 10.1515/ausp-2015-0052

\title{
Multilingualism and Education in Transylvania
}

\author{
Attila BENŐ \\ Babeş-Bolyai University of Cluj-Napoca \\ Faculty of Letters \\ Hungarian and General Linguistics Department \\ attilabe@yahoo.com
}

\begin{abstract}
The topic of this paper is the situation of language skills and a determining factor of it in minority context: languages of instruction in Transylvania. Presenting the socio-demographic context and the status of languages as they are manifested in language skills. Language skills are presented referring to mother tongue skills, second and foreign language competence. The paper emphasizes that the connection between schooling, education, and language usage is evident in the case of minority languages since the instruction in minority languages is a key factor for the maintenance of the language. The empirical data used in the paper come from several sources, most important of them being a sociolinguistic survey in a representative sample of Hungarians in Transylvania carried out by The Romanian Institute for Research on National Minorities (Cluj/Kolozsvár) in 2009.
\end{abstract}

Keywords: bilingualism, language skills, education, linguistic rights

\section{Language skills in minority and majority context}

Transylvania as a historical region has been characterized by multilingualism for centuries. ${ }^{1}$ The widespread bilingualism and multilingualism of the inhabitants in the region is often mentioned in historical and literal works.

In the background of multilingualism is the history of a multiethnic region, linguistic and cultural contacts, and many territorial changes through which Romania passed in the $20^{\text {th }}$ century, and as a consequence the majority-minority status change of Hungarians and Romanians in Transyilvania. Presenting the current socio-demographic context and the status of languages as they are

1 The term Transylvania was used to refer to the historical Transylvania, the central part of the country. But today the term conventionally includes not only the historical Transylvania, which was part of the Hungarian kingdom, but also the provinces of Banat, Crişana, and Maramureş. We use the term Transylvania in this broader sense. 
manifested in language skills, I focus on education as a determining factor for language skills and for the vitality and the usage of languages. The connection between schooling, education, and language usage is evident in the case of minority languages since the instruction in minority languages is a key factor for the maintenance of the language (Skutnabb-Kangas 2000).

\subsection{Socio-demographic context}

At present, there are six ethnic groups living in Transylvania: Romanians, Hungarians, Romas, Germans, Ukrainians, and Slovaks. According to the last census (2002), Romanians (74.69\% of the population) and Hungarians (19.6\%) together form $94.29 \%$ of the Transylvanian inhabitants. Thus, the Hungarian ethnic group is still the largest minority community in Transylvania, although their proportion has been decreasing almost continuously in the last decades: in 1956, 25\% of the population in Transylvania was of Hungarian identity, while in 2011 that proportion was $17.9 \%$ (see Table 1).

Table 1. The number and percentage of Romanians and Hungarians in Romania and Transylvania between 1956 and 2002 2

\begin{tabular}{ccccc}
\hline Year & $\begin{array}{c}\text { Total population } \\
\text { of Romania }\end{array}$ & $\begin{array}{c}\text { Total population } \\
\text { of Transylvania }\end{array}$ & $\begin{array}{c}\text { Romanians in } \\
\text { Transylvania }\end{array}$ & $\begin{array}{c}\text { Hungarians in } \\
\text { Transylvania }\end{array}$ \\
\hline 1956 & $17,489,450$ & $6,218,427$ & $4,041,156$ & $1,558,254$ \\
& & & $(64.98 \%)$ & $(25.05 \%)$ \\
\hline 1966 & $19,103,163$ & $6,719,555$ & $\begin{array}{c}4,559,432 \\
(67.85 \%)\end{array}$ & $\begin{array}{c}1,597,438 \\
(23.77 \%)\end{array}$ \\
\hline 1977 & $21,559,910$ & $7,500,229$ & $5,203,846$ & $1,691,048$ \\
& & & $(69.38 \%)$ & $(22.54 \%)$ \\
\hline 1992 & $22,810,035$ & $7,723,313$ & $5,684,142$ & $1,603,923$ \\
& & & $(73.59 \%)$ & $(20.76 \%)$ \\
\hline 2002 & $21,680,947$ & $7,221,733$ & $5,393,552$ & $1,415,718$ \\
& & & $(74.69 \%)$ & $(19.6 \%)$ \\
\hline $2011^{2}$ & $20,121,641$ & $6,789,250$ & $4,794,577$ & $1,216,666$ \\
& & & $(70.62 \%)$ & $(17.92 \%)$ \\
\hline
\end{tabular}

The decrease in the number of the Hungarians between 1977 and 2011 might be due to three factors: law birth rate, emigration, and assimilation (BenóSzilágyi 2005: 136).

2 Source: National Institute of Statistics. http://www.recensamantromania.ro/rezultate-2/ 


\subsection{Language skills and the relationship of languages}

The researches made recently about the language skills of the population in Romania and Transylvania suggest that bilingualism and multilingualism among Hungarians in Transylvania is widespread. 93\% of the Hungarians declared that they could speak at least one language besides their mother tongue and almost half $(44 \%)$ of them considered that they can speak at least two other languages. These proportions are above the European and Romanian average (see Table 2).

Table 2. Do you know any other language besides your mother tongue? (at least at conversational level)

\begin{tabular}{ccccc}
\hline & None (\%) & $\begin{array}{c}\text { At least one } \\
(\mathbf{\%})\end{array}$ & $\begin{array}{c}\text { At least two } \\
\mathbf{( \% )}\end{array}$ & $\begin{array}{c}\text { At least } \\
\text { three (\%) }\end{array}$ \\
\hline $\mathrm{EU}(2006)^{3}$ & 44 & 56 & 28 & 11 \\
\hline Romania $^{4}$ & 53 & 47 & 27 & 6 \\
\hline $\begin{array}{c}\text { Hungarians in } \\
\text { Romania }^{5}\end{array}$ & 7 & 93 & 44 & 16 \\
\hline
\end{tabular}

The previous surveys and estimates also related that $80-90 \%$ of Hungarians in Transylvania are bilinguals (Csepeli et al., Péntek 2001a).

If we compare the Hungarians' and Romanians' language skills according to their own admission, we can see an evident asymmetry: most of the Hungarians in Transylvania can speak Romanian; meanwhile, the majority of Romanians cannot use Hungarian. According to these data, 83.9\% of the Hungarians can speak well Romanian, but $7.34 \%$ Romanians in Transylvania declared that they understand no word or only a few words in Hungarian. The differences at others levels of language competence are also significant (see Table 3). The asymmetry is due to the fact that Romanian-speaking students do not learn Hungarian language in public schools and they are not encouraged to learn Hungarian in any way.

3 European Commission: Europeans and their languages. Special EUROBAROMETER 243, 2006: 9-13

4 Ibidem

5 Horváth-Veress-Vitos 2010: 40 
Table 3. Hungarians' and Romanians' language skills in Transylvania ${ }^{6}$

\begin{tabular}{lcc}
\hline & $\begin{array}{c}\text { Romanian language } \\
\text { skills of Transylvanian } \\
\text { Hungarians (\%) }\end{array}$ & $\begin{array}{c}\text { Hungarian language } \\
\text { skills of Romanians in } \\
\text { Transylvania (\%) }\end{array}$ \\
\hline $\begin{array}{l}\text { I speak the language as } \\
\text { mother tongue }\end{array}$ & 10.6 & 2.52 \\
\hline I speak the language fluently & 24.8 & 2.88 \\
\hline I speak it well with accent & 27.4 & 2.16 \\
\hline $\begin{array}{l}\text { In most of the cases, I can } \\
\text { make myself understood } \\
\text { speaking the language }\end{array}$ & 21.1 & 7.19 \\
\hline $\begin{array}{l}\text { I can make myself } \\
\text { understood with difficulty }\end{array}$ & 9.7 & 9.71 \\
\hline $\begin{array}{l}\text { I understand only a few } \\
\text { words }\end{array}$ & 5.5 & 23.74 \\
\hline I understand no word & 0.9 & 51.8 \\
\hline
\end{tabular}

In 2009, The Romanian Institute for Research on National Minorities (Cluj/ Kolozsvár) carried out a sociolinguistic survey in a representative sample of Hungarians. ${ }^{7}$ Since the sample consisted of more than 4,000 Hungarian-speaking respondents, the empirical data make possible the analyses of the correlations between different social variables and language skills.

The questionnaire also gathered information about the second or third language as foreign language. The admitted foreign language knowledge shows important differences among Hungarians and Romanians in Transylvania, especially if we focus on German and French language competence. The proportion of German languages skills at conversational level among Hungarian-speaking respondents is $20 \%$, while that proportion is $6 \%$ among Romanians. The French communicative competence seems to be more general among Romanians, since $24 \%$ of them declared that they could have a conversation in French; among Hungarians that proportion is only $11 \%$ (Table 4 ). These facts are rooted in the different traditions of foreign language learning among Hungarians and Romanians (Hungarian-German and Romanian-French cultural connections are well documented in history).

$6 \quad$ Horváth 2003: 16-17

7 I want to express my acknowledgment to Mr. István Horváth for providing access to the empirical data of the survey. 
Table 4. Respondents able to participate in a conversation in a foreign language (in percentage)

\begin{tabular}{lccc}
\hline & English (\%) & German (\%) & French (\%) \\
\hline EU $(2006)^{8}$ & 38 & 14 & 14 \\
\hline Romania $^{9}$ & 29 & 6 & 24 \\
\hline Hungarians in Romania $^{10}$ & 30 & 20 & 11 \\
\hline
\end{tabular}

If language skills are analysed according to the socio-demographic variables, certain differences are evident: Hungarian speakers living in countryside know in a lesser degree both the state language (Romanian) and a foreign language than those who live in large towns. The differences are even more striking between younger and older speakers. Almost $20 \%$ of the young respondents (18-34 years old) declared that they spoke English very well. That proportion is 5.3\% among middle-aged (3354 years old) respondents and $1.2 \%$ among older respondents (Diagram 1).

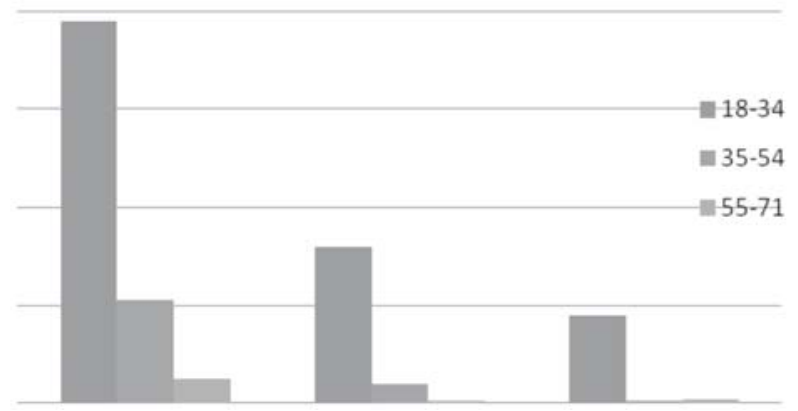

Diagram 1. English language skills and the age of respondents

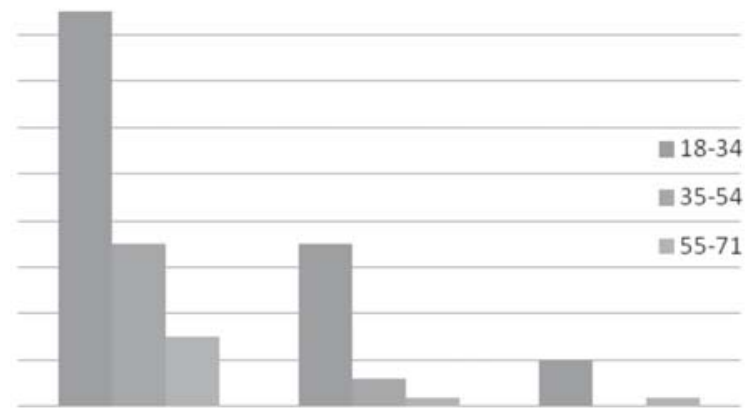

Diagram 2. German language skills and the age of respondents

8 European Commission: Europeans and their languages. Special EUROBAROMETER 243, 2006: 9-13

9 Ibidem

10 According to the survey carried out in 2009 by the The Romanian Institute for Research on National Minorities. 
German language skill differences are also significant regarding age: younger respondents declared to a greater extent that they can speak Germany very well or at an advanced level (Diagram 2).

As it could be expected, the level of education is also correlated with the second and third language skills: the more educated was the respondent, the more often he/she declared that he/she can use a second or a third language at a higher level.

\section{Multilingualism, education, and minority linguistic rights}

In general, being bilingual or multilingual is an advantage, but in minority situation this advantage is not always obvious since the possibilities of studying in the mother tongue for ethnic minorities are limited at higher level in a "national state," and the minority students have to choose from fewer specializations if they insist on learning in their mother tongue.

As a consequence of this situation, the persons belonging to ethnic minorities are in disadvantageous positions on the labour market since the labour market has also got a "specific cultural-symbolic component, structuring cultural elements and language skills" (Sorbán 2011). According to the census data from 2002, the situation of Hungarians in Romanian employment areas is different from the Romanians: the Hungarians remain underrepresented in management positions and in the sphere of intellectuals, but they are over-represented within skilled and unskilled workers or in the fields of commerce or services (Veres 2007: 47). In that situation, bilingualism or multilingualism is a real chance - only if any kind of biases are eliminated and the languages are used accurately with selfconfidence, in professional sphere and everyday life, too (Sorbán 2014).

Since language skills and the positions on the labour market are closely connected to education, to the language of instruction, and to the methods of language teaching in public education, it is worth analysing the education system as a background of multilingualism in Romania.

Although after 1989 the education system in Romania has developed, many problems of the ethnic minority education remained unsolved. In the following, we will try to give a general picture of the status of education in minority languages in the pre-university education system as well as in higher education and will try to emphasize the prestige and the function of languages in a bilingual or multilingual context. 


\subsection{Pre-university education system}

In Romania, there are three types of education for ethnic minority children:

1. Educational structures with tuition in the native language for the Czech, Croatian, German, Hungarian, Serbian, Slovakian, and Ukrainian minority. These structures include 2,732 educational units in which 209,842 children and pupils study.

2. Educational structures with partial tuition in the native language in 5 schools including 561 children and pupils. This form of study is characteristic for the Croatian, Turkish, and Tartar minorities, for whom some vocational subjects are also taught in the native language.

3. Educational structures in Romanian language where the native languages are also studied if there are demands for that study. That includes 387 schools with 30,964 pupils. Such structures are organized for the native languages of the Armenian, Bulgarian, Greek, Italian, Polish, Roma, Russian, Czech, Croatian, German, Hungarian, Serbian, Slovakian, Turkish-Tartar, and Ukrainian minorities. $^{11}$

The maintenance of minority languages can be assured only by the first type of education. All the other types of education help the language shift process in which the minority groups have been involved for decades. Language shift in that case means the losing of the mother tongue in favour of the official language, which is the language of the majority group.

In 2002, the Romanian Ministry of Education and Research (MER) published a report about the education of minorities and the presence of minority languages in the Romanian education system (MER 2002). In that report, we find data about the presence of minority languages in different levels of education as well as about the language of instruction. Comparing the report data to the last census's demographical data (2002), one can see the proportion of education in minority languages in different education levels as compared to the country-wide data. Making that comparison, we found that the education in minority languages is underrepresented according to the number of pupils present in Romanian public education with mother tongue compared to the total number of ethnic minorities (see Table 5). 
Table 5. Presence of minority languages in different educational levels. (The percentages are referring to the proportion of the population or of the ethnic group engaged in a certain level of education with mother tongue tuition.)

\begin{tabular}{|c|c|c|c|c|c|c|}
\hline \multirow[t]{2}{*}{ Educational level } & \multicolumn{2}{|c|}{$\begin{array}{c}\text { Total - } \\
\text { country }\end{array}$} & \multicolumn{2}{|c|}{$\begin{array}{c}\text { Total - } \\
\text { minorities }\end{array}$} & \multicolumn{2}{|c|}{$\begin{array}{c}\text { Total - } \\
\text { Hungarians }\end{array}$} \\
\hline & $\mathbf{N}$ & $\%$ & $\mathbf{N}$ & $\%$ & $\mathbf{N}$ & $\%$ \\
\hline Pre-school education & 616,014 & 2.84 & 46,351 & 2.03 & 40,266 & 2.81 \\
\hline $\begin{array}{l}\text { Primary education } \\
\text { (grades I.-IV.) }\end{array}$ & $1,028,697$ & 4.74 & 57,814 & 2.53 & 51,609 & 3.6 \\
\hline $\begin{array}{l}\text { Middle school education } \\
\text { (grades V.-VIII.) }\end{array}$ & 1,839 & 5.95 & 63,927 & 2.8 & 57,889 & 4.03 \\
\hline $\begin{array}{l}\text { Secondary education (grades } \\
\text { IX.-XII./XIII.) }\end{array}$ & 710,663 & 3.27 & 32,626 & 1.43 & 28,301 & 1.97 \\
\hline Vocational education & 252,347 & 1.16 & 7,090 & 0.31 & 7,090 & 0.49 \\
\hline Post-secondary education & 72,685 & 0.33 & 2,034 & 0.08 & 2,001 & 0.13 \\
\hline
\end{tabular}

In pre-school education, tuition in the native language of the minorities is close to the total country proportion (especially in the case of the Hungarian minority): $2.84 \%$ of the population is engaged in pre-school education and the proportion of Hungarians in pre-school education having native language instruction is $2.81 \%$ (compared to the Hungarian population in Romania).

In middle school (grades V.-VIII.) and secondary education (grades IX.XII./XIII.), ethnic minorities getting mother tongue instruction is largely underrepresented. At these levels, the proportion of mother tongue instruction for ethnic minorities is less than half of the total country proportion: in middle school education, it is $2.8 \%$, while country-wide that proportion is $5.95 \%$.

At the level of vocational and post-secondary education, the possibilities of studying in native language are even more reduced for the ethnic minorities: the proportion of ethnic minorities who study in their mother tongue at these levels is just one quarter of the country's overall proportion.

According to these proportions, the instruction in Hungarian is better organized than the instruction in other minority languages due to the fact that ethnic Hungarians in Romania consider native-language education ranging from nursery school to university as a natural and rightful demand. In the early 1900s, Transylvania had a highly developed Hungarian educational network where instruction in Hungarian took place at every level. And, of course, the Hungarians' numerical ratio and their historic traditions are a strong base for the functioning of mother tongue tuition at all educational levels.

It is worth mentioning that in Romanian public (general) education more than 150,000 pupils are learning in Hungarian (the number of Hungarian teachers is 12,000). Although there are 58 Hungarian schools and 138 bilingual 
(Hungarian-Romanian) schools, the Hungarian community has no power of decision concerning the matters of education. Since the possibility for learning in Hungarian in certain regions is reduced, and the possibilities for continuing higher education in Hungarian is uncertain, about 50,000 (25-30\%) of the Hungarianspeaking pupils are learning in Romanian in the pre-university education system.

Since there is a lack of continuity in native-language education and the possibilities are reduced for vocational training in mother tongue, a large number of students of ethnic minority origin are forced during their primary school years to Romanian-language schools. ${ }^{12}$ Council of Europe, Second opinion on Romania mentions certain problems of education for minorities:

"17. (...) Shortcomings however persist in the education area, in particular for numerically smaller minorities, and it is to be hoped that the new decentralized system of financing education will make it possible to better meet the existing needs. ${ }^{13}$

\subsection{Higher education}

In higher education, the ethnic minorities are underrepresented both in their number and proportion as well as in the participation of their native language in the education. According to the report elaborated by the Romanian Ministry of Education and Research, the proportion of students of ethnic minority origin is half of the general (country-wide) proportion. In the case of ethnic minorities, $1.31 \%$ of the total ethnic minority population is studying in higher education, while for the total number of Romanian citizens that proportion is $2.63 \%$ (see Table 6).

Table 6. Participation of ethnic minorities in higher education

\begin{tabular}{|c|c|c|c|c|c|c|c|c|c|}
\hline \multirow[t]{2}{*}{$\begin{array}{c}\text { Academic } \\
\text { year }\end{array}$} & \multicolumn{2}{|c|}{$\begin{array}{c}\text { Total } \\
\text { number and } \\
\text { proportion } \\
\text { of students }\end{array}$} & \multicolumn{2}{|c|}{$\begin{array}{c}\text { Total number } \\
\text { and prop. of } \\
\text { ethnic minority } \\
\text { students }\end{array}$} & \multicolumn{2}{|c|}{$\begin{array}{l}\text { Hungarian- } \\
\text { speaking } \\
\text { students }\end{array}$} & \multicolumn{2}{|c|}{$\begin{array}{c}\text { Difference } \\
\text { for } \\
\text { Hungarian } \\
\text { students } \\
\end{array}$} & \multirow{2}{*}{$\begin{array}{c}\begin{array}{c}\text { Hungarian } \\
\text { students } \\
\text { trained in } \\
\text { Hungarian }\end{array} \\
\mathrm{N} \\
\end{array}$} \\
\hline & $\mathrm{N}$ & $\%$ & $\mathrm{~N}$ & $\%$ & $\mathrm{~N}$ & $\%$ & $\mathrm{~N}$ & $\%$ & \\
\hline 2001-2002 & 571,613 & 2.6 & 30,043 & 1.3 & 24,598 & 1.7 & 13,172 & 0.9 & $8-10,000$ \\
\hline
\end{tabular}

In the academic year 2001-2002, the number of Hungarian-speaking students in higher education was 25,000 , and only $30-40 \%$ of them $(8-10,000$ students) were trained in Hungarian. That proportion is valid nowadays, too. If we take

12 It was recommendend in 1997 to Romania by the Coucil of Europe: "It takes note of the Romanian authorities' resolve to further the rights of national minorities and especially to amend the 1995 Education Act so as to allow mother tongue instruction for members of national minorities." (Resolution 1123 on the honouring of obligations and commitments by Romania)

13 Advisory Committee on the Framework Convention for the Protection of National Minorities. Second Opinion on Romania, adopted on 24 November 2005. 
into consideration that in Romania, with a population of 21.6 millions and 571,613 students learning in higher education, for the Hungarians in Romania that proportion should be 37,770 . The difference is 13,172 , which is referring to the number of Hungarian-speaking students who are missing to have the same proportion for the Hungarian-speaking students as the nation-wide proportion. In another approach: for 1,000 inhabitants, the number of students is 26 in Romania and for the Hungarian-speaking community in Romania that number is 17.1. That means that a Hungarian-speaking Romanian citizen has less opportunity to study in higher education than Romanian-speaking Romanian citizens.

As it was mentioned, the Hungarian training in the state universities in Romania does not cover all the fields: there are no possibilities to study in Hungarian technical sciences, agricultural studies and the possibilities are reduced for studying law, music, and fine arts in Hungarian. That is why the demand for a state university with Hungarian instruction is well-founded. But the Law of Education does not allow the setting up of a Hungarian-language state-funded university (although there are more than 54 state universities in Romania), but allows only for a multicultural university whose language of instruction is regulated by a separate law. In the field of Hungarian-language higher education, the establishment by the Hungarian government of the Sapientia Hungarian University of Transylvania represented a big step forward.

At present, instruction in the Hungarian language is offered by certain faculties and specializations at the following universities: the Babeş-Bolyai University of Cluj, the University of Medicine and Pharmacology Târgu Mureş, the Theatrical University of Târgu Mureş, and the Faculty of Hungarian Studies at the University of Bucharest. The Romanian law on education also puts in the category of private schools the denominational institutes of education. Such institutions include the Hungarian-language university-level Protestant Theological Institute of Cluj, The Catholic Theological University of Alba Iulia, and the Partium Christian University of Oradea.

In some universities of Romania, there are organized sections of study and specialization in other minority languages, too: "Babeş-Bolyai" University of Cluj-Napoca - German, Romany, and Yiddish; University of Bucharest - Slovak, German, Turkish, Russian, Ukrainian, Bulgarian, Romany; Academy of Dramatic Art of Timişoara - German; "Lucian Blaga" University of Sibiu, Theatrical Art Department - German; "Politehnica" University of Bucharest - German; "Politehnica" University of Timişoara - German; West University of Timişoara - Czech and Serbian; University of Suceava - Ukrainian and Polish; "Ovidius" University of Constanța - Turkish. 
All this data show that the situation of education for minorities is very complex in Transylvania. For larger ethnic and linguistic minorities (Hungarian, German), the possibilities for learning in mother tongue is assured at certain levels, while for other minorities the language of education is Romanian and the mother tongue can be taught only if there is any demand for this type of instruction. Different minorities have different demands and expectations considering their right for education in mother tongue. Their loyalty to mother tongue is also different among the ethnic minorities, and in their national identity the mother tongue plays different roles.

Thus, for example, the problem of academic education is insistently tackled in the Hungarian publications. The other ethnic groups either do not discuss the problem or declare themselves satisfied with the solutions, the judicial frame offered by the Law on Education.

What is common for all ethnic minorities in Transylvania is the problem of maintaining their mother tongue and culture in the conditions of decreasing in number and missing very important linguistic rights in Romanian legal codification and in official practice (Benő-Péntek 2003).

\section{References}

Benő, Attila-Péntek, János. 2003. Die juristische Regelung des Sprachgebrauchs in Rumanien und die sprachlichen Rechte der Muttersprachensprecher. In: Sprache und die Kleinen Nationen Ostmitteleuropas Begegnungen. Schiftenreihe des Europa Institutes Budapest. Band 21: 71-86. Europa Institut Hrsg. Ferenc Glatz.

Benő, Attila-Szilágyi, N, Sándor. 2005. Hungarian in Romania. In: Anna Fenyvesi (ed.), Hungarian language contact outside Hungary. Amsterdam/Philadelphia: John Benjamins Publishing Company, pp. 133-162.

Gohma 2006. Government Office for Hungarian Minorities Abroad: The situation of Hungarians in Romania in 2006. www.hhrf.org/htmh/en/?menuid=0404.

Horváth, István. 2003. Az erdélyi magyarok kétnyelvúsége: nyelvmentés és integráció között? Erdélyi Társadalom 1: 7-24.

Horváth, István-Veress, Ilka-Vitos, Katalin. 2010. Közigazgatási nyelvhasználat Hargita megyében és a központi kormányzat megyeszintú intézményeiben. Cluj/Kolozsvár: Institutul Pentru Studierea Problemelor Minorităților Naționale. Working Papers in Romanian Minority Studies.

MER 2002. Ministry of Education and Research. The present time in the education of national minorities in Romania. 
Skutnabb-Kangas, Tove. 2000. Nyelvi emberi jogok. In: Klára Sándor (ed.), Nyelv és hatalom, nyelvi jogok és oktatás. Csíkszereda: Apáczai Csere János Pedagógusok Háza Kiadója, pp. 111-123.

Sorbán, Angella. 2014. Kisebbség és kétnyelvúség. A kétnyelvűség szociológiai aspektusai az oktatásban és a munkaerőpiacon. Anyanyelvápolók Erdélyi Szövetsége Kiadó: Sepsiszentgyörgy.

Veres, Valér. 2007 Az erdélyi magyarok demográfiai képe az ezredforduló után, a 2002-es népszámlálási adatok tükrében. Max Weber Társadalomkutató Alapítvány, Kolozsvár. 